\title{
SCREENING OF EPIPHORA PATIENTS THROUGH ENDOSCOPIC EXAMINATION OF INFERIOR MEATUS
}

\author{
By \\ Mohamed H. Mostafa, Atef A. El-Maraghy and Ahmed M. Abd El- \\ Fattah \\ Department of Otorhinolaryngology Faculty of Medicine, Al-Azhar University, Egypt \\ E-mail: medohasan02@gmail.com
}

\begin{abstract}
Background: Epiphora is a common disease and has many causes which may be due to obstruction along the nasolacrimal system. Inferior meatus pathology is common but inferior meatus is not routinely evaluated. So, any patient with epiphora, nasal examination is mandatory and inferior meatus must be evaluated.

Objective: Examination of the inferior meatus and nasolacrimal duct orifice in patients with epiphora, and estimation of the percentage degree of nasal causes in cases of epiphora,

Patients and Methods: This retrospective study was carried out on fifty consecutive patients who attended to outpatient clinic, Al-Azhar University Hospitals (Al-Hussein and Sayed Galal University Hospitals) between September 2019 and June 2020. They were complaining of persistent bilateral or unilateral epiphora. All of them underwent trans-nasal endoscopic examination of inferior meatus for any lesion obstructing the opening of nasolacrimal ducts. This occurred by use of $2.8 \mathrm{~mm} 30$ degree endoscope.
\end{abstract}

Results: There were 15males (30\%) and 35 females (70\%).The mean age of included cases were 53.16 years. Thirty two patients appeared normal (64\%),10 patients with hypertrophied mucosa at the orifice (20\%).2 patients with dacryolith (4\%), 2 patients with synechia obstructing the orifice $(4 \%), 3$ patients with cystic obstruction (6\%), and one patient with mucosal plug at the orifice (2\%). Females were mostly affected. Most of patients were unilaterally affected and most of them had hypertrophied mucosa at the nasolacrimal orifice.

Conclusion: Inferior meatus endoscopy should be routinely performed in patients with epiphora to identify any pathology which may be easily corrected.

Key words: epiphora, meatus, endoscopic examination.

\section{INTRODUCTION}

The lacrimal system has secretory and excretory components. Normally, there is a balance between the production of tears and drainage of tears. When this balance is affected, either the secretory or the excretory component may produce epiphora (Patel et al., 2020). The lacrimal drainage apparatus is divided into the upper and lower sections. The proximal section includes the punctum, canaliculus, and the common canaliculus. The lower lacrimal drainage system consists of the lacrimal sac and the nasolacrimal duct that finally open into the lateral nasal wall below the inferior meatus Kels et al. (2015) and Patel et al.(2020).

Epiphora is a common proplem evaluated by ophthalmologists and otolaryngologists. It is typically the result of obstruction at some level of nasolacrimal system the canaliculi, sac, or 


\section{MOHAMED H. MOSTAFA et al.,}

ducts. Multiple etiologies exists including scarring from infection or trauma, operation, tumors, masses, cysts, and thicking of the mucosa at the nasolacrimal duct orifice DelGaudio and Wojno, (2010). Sacal and post sacal obstructions are more common than pre sacal obstruction. Obstructions at the level of Hasners valve are rare (Eloy et al., 2012). Lacrimal duct obstruction is a common eye disease which accounts over $50 \%$ of the cases of epiphora (Ye et al., 2015).

Nasolacrimal duct obstruction may be congenital or acquired (Dantas, 2010). Congenital nasolacrimal duct obstruction is common, with incidence of up to 30 percent of term newborns. The majority of these cases are asymptomatic and selflimited, and is related to incomplete canalization (Rogers et al., 2010 and Vagge et al., 2018).

Acquired NLD obstruction is primary and secondary is more likely to require procedural intervention. Inflammatory conditions, foreign materials, infection can lead to an obstructed NLD.

The present study aimed to evaluate the nasolacrimal duct opening in epiphora patients through endoscopic nasal examination .

\section{PATIENTS AND METHODS}

This retrospective study was carried out on fifty patients who attended to outpatient clinic of Al-Hussien \&Bab elsharia University Hospitals from September 2019 to June 2020. Some patients with uni later or bilateral epiphora, males or females.
Ophthalmologic workup was done for these patients who included routine ophthalmological examination and irrigation of the naso lacrimal system.

Otolaryngology examination included a complete head and neck examination along with rigid endoscopy of the inferior meatus and naso lacrimal orifice. Nasal endoscopy was performed after administration of topical anesthetic and decongestant spray with a $2.8 \mathrm{~mm} 30$ degree endoscope.

The scope was passed under the inferior turbinate, and the area of the naso lacrimal duct orifice was identified and examined for abnormalities, including edema, submucosal fullness, or a soft tissue mass.

During examination of the area of the naso lacrimal duct orifice endoscopically, the nasolacrimal sac was palpated in the medial canthal area and compressed repeatedly to try to express tears through the nasolacrimal duct.

Increasing soft tissue fullness and failure to express tears through the nasolacrimal orifice helped to confirm the presence of obstruction.

\section{Statistical analysis:}

Recorded data were analyzed using the statistical package for the social sciences, version 20.0 (SPSS Inc., Chicago, Illinois, USA). Quantitative data were expressed as mean \pm standard deviation (SD). Qualitative data were expressed as frequency and percentage.

\section{RESULTS}


Fifty patients were evaluated for epiphora with inferior meatus endoscopy, including 15 males (30\%) and 35 females $(70 \%)$ The mean age at presentation was 53 years (range 35-70 years), 5 patients (10\%) from 35 to 40 years, 10 patients (20\%) from 40 to 45 years, 15 patients (30\%) from 45 to 55 years, 17 patients
(34\%) from 55 to 65 years and 3 patients (6\%) more than 65 years. Twelve $(24 \%)$ of the patients reported bilateral epiphora, $38(76 \%)$ of them were unilateral. 30 $(60 \%)$ patients had only left-sided symptoms, and 8 patients had only rightsided symptoms (16\%) (Table 1).

Table (1): Distribution of epiphora patients according to their demographic data regarding sex, age, side

\begin{tabular}{|c|c|c|}
\hline Sex & & Total $(\mathrm{n}=50)$ \\
\hline Male & & $15(30 \%)$ \\
\hline Female & & $35(70 \%)$ \\
\hline Age (years) & & Total $(n=50)$ \\
\hline 35_40 years & & $5(10 \%)$ \\
\hline $40-45$ years & & $10(20 \%)$ \\
\hline$>45-55$ years & & $15(30 \%)$ \\
\hline$>55-65$ years & & $17(34 \%)$ \\
\hline$>65$ years & & $3(6 \%)$ \\
\hline Range [Mean \pm SD] & & $35-70[53.16 \pm 9.41]$ \\
\hline Side & No. & $\%$ \\
\hline Bilateral & 12 & $24 \%$ \\
\hline Left & 30 & $60 \%$ \\
\hline Right & 8 & $16 \%$ \\
\hline Total & 50 & $100.0 \%$ \\
\hline
\end{tabular}

Office endoscopic examination of the 50 patients with 62 sides revealed normal appearance in 32 patients $(64 \%), 8$ of them were bilateral, 24 were unilateral, 8 of them were males and 24 were females. Apparent obstruction of the nasolacrimal duct orifice in 22 side (18 patients), with inability to manually express tears.

Findings in these patients included two patients $(4 \%)$ with adhesion and synechia of the nasal cavity and in inferior meatus after operation leading to obstruction of the nasolacrimal duct orifice, both were males and unilateral, one was Rt sided and one was left sided. They had a previous endoscopic sinus surgery.

Three apparent nasolacrimal duct orifice cysts $(6 \%)$ one of them was a male and two were females, one of them was bilateral, two were unilateral, one of them was Rt sided and one was left sided (6\%).

Two patients with dacryolith (4\%) both were males and all left sided (4\%). One patient $(2 \%)$ with mucosal plug at the orifice he was left sided male.

10 cases $(20 \%)$ of patients with hypertrophy or edema of the mucosa around the nasolacrimal duct orifice, 3 of them were bilateral (6 sides) and 7 patients were unilateral, two of them were Rt sided and 5 were left sided. as regard to the gender there were 15 males 8 of them with normal nasolacrimal duct opening, two patients with synechia, two with dacryolith, two patients with hypertrophied mucosa at the opening and one patient with cyst obstructing the opening. There were 35 females 24 of them with normal nasolacrimal opening, 8 
with mucosal hypertrophy, one with obstructing the opening (Table2).

mucosal plug and one patient with cyst

Tabel (2): Distribution of epiphora patients according to their sex, side, and pathology

\begin{tabular}{|c|c|c|c|c|c|c|c|c|c|c|}
\hline Patients & $\mathrm{N}$ & $\%$ & Bilateral & \multicolumn{3}{|c|}{ Unilateral } & Male & $\%$ & female & $\%$ \\
\hline \multirow{2}{*}{ Normal } & \multirow{2}{*}{32} & \multirow{2}{*}{64} & \multirow{2}{*}{8} & Total & $\mathrm{Rt}$ & $\mathrm{Lt}$ & \multirow{2}{*}{8} & \multirow{2}{*}{16} & \multirow{2}{*}{24} & \multirow{2}{*}{48} \\
\hline & & & & 24 & 4 & 20 & & & & \\
\hline Synechia & 2 & 4 & $\begin{array}{ll}--- \\
--\end{array}$ & 2 & 1 & 1 & 2 & 4 & 0 & 0 \\
\hline Dacryolith & 2 & 4 & & 2 & 0 & 2 & 2 & 4 & 0 & 0 \\
\hline Mucosal plug & 1 & 2 &  & 1 & 0 & 1 & $=$ & 0 & 1 & 2 \\
\hline Cyst & 3 & 6 &  & 2 & 1 & 1 & 1 & 2 & 2 & 4 \\
\hline $\begin{array}{l}\text { Hypertrophied } \\
\text { mucosa }\end{array}$ & 10 & 20 & 3 & 7 & 2 & 5 & 2 & 4 & 8 & 16 \\
\hline Total & 50 & 100 & 12 & 38 & 8 & 30 & 15 & 30 & 35 & 70 \\
\hline Percentage $\%$ & 50 & 100 & 24 & 76 & 16 & 60 & & & 7 & \\
\hline
\end{tabular}

\section{DISCUSSION}

This study represented a case series of patients with constant epiphora evaluated with IM endoscopy. They were 50 patients with 62 nasolacrimal systems, 18 of them (22 sides) had pathology at the IM, 32 patients (40 sides) were free. The females were more affected than males i.e $35(70 \%)$ and $15(30 \%)$ respectively. Consistent with our finding, Viso et al., (2012) reported that women had a higher prevalence epiphora than men.

In our study, there were 18 patients with a pathology at the nasolacrimal duct orifice ,eleven were female $(61 \%)$ and seven were male $(39 \%)$ consistent with our finding, Nemet and Vinker reported that nasolacrimal duct obstruction affects women more than males $\left(65 \% \_73 \%\right)$ this could be due to narrow and long nasolacrimal ducts in female (Nemet and Vinker, 2014). This consistent also with Shen et al. (2016) where he reported that nasolacrimal obstruction more in female with a rate $(65.6 \%)$, may be due to smaller diameter, longer lacrimal canal, inferior bony lacrimal fossa.
In our study, there were $(76 \%)$ patients with unilateral epiphora and (24\%) patients were bilateral. consistent with our finding, patel $J$ et al., Shen et al., reported in their studies that about $75 \%$ of cases of nasolacrimal duct obstruction is unilateral (Shen et al., 2016 and Patel et al., 2020).

In our study, there were only two patients male 52 years and 66 years old with dacryolith (4\%), this consistent with Gad palli et al., (2011) and Mishra et al. (2017) that reported in their studies that the dacryolith is an un usual cause of the naso lacrimal duct obstruction and there is a high success rate and favorable prognostic value with endo nasal endoscopic management than an open or external approach (Gadpalli c et al., 2011 and Mishra et al.,2017). This was against Roger et al. (2010), where there was one patient with dacryolith $(5.8 \%)$ and he was a male 33 years old. This difference may be due to different numbers of the total cases, but there was a consistent with him that males mostly affected than females.

In our study, there were 3 patients $(6 \%)$ with cysts at the nasolacrimal duct 
orifice: one was male patient and two were females. They were between (55-65) years old, This was against Roger et al. (2010) who reported that there were $17 \%$ with cysts at the nasolacrimal duct orifice, and were females with age above 60 years old. This difference may be due to different numbers of cases. This consistent with Eloy et al. (2012), Daraie and DelGaudio et al. (2014) reported that nasolacrimal duct orifice cysts also described in the adult population, with correct management are an easily revisable cause of epiphora.

In our study, there was one female patient aged 45 years old with left sided epiphora with a mucosal plug obstructing the nasolacrimal duct orifice. This consisted with Roger et al. (2010) where he reported one case of mucosal plug female old age.

In our study, there were two cases of epiphora due to fibrous band (synechia) occluding the orifice of the duct. They were males with 40 and 50 years old. This was consistent with Ali et al. (2015) as he reported that nasolacrimal duct obstruction can be caused by injury during maxillary sinus surgery or obstruction after surgery. Most cases of nasolacrimal duct obstruction due to synechia or injury during operation are transient and permanent nasolacrimal duct obstruction rarely occurs because goblet cells secret mucin which has anti adhesion effect helpful for prophylaxis against obstruction (Takahashi et al., 2013).

In our study, there were $20 \%$ of cases with hypertrophied and thick mucosa at the nasolacrimal duct opening. This was against Roger et al. (2010) where there were $52 \%$ of patients were with hypertrophied mucosa at nasolacrimal duct. This difference may be due to decrease in the total number of patients. But consistent with him the two studies concluded that most patients are unilateral females old age .This consisted with Eriman et al. (2012) who concluded that there were $23 \%$ of patients with unilateral epiphora. Chronic inflammation of the nasal mucosa can lead to epiphora by causing edema and thickness around nasolacrimal duct orifice. In these studies most patients were unilateral.

Obstruction of the nasolacrimal duct and its orifice was the most common cause of epiphora. Nasolacrimal duct and inferior meatus are often left unexamined in some epiphora patients.

\section{CONCLUSION}

Routine endoscopic examination and evaluation of the naso lacrimal duct orifice in the inferior meatus should be applied in all epiphora patients. This evaluation can help to identify pathology that may be easily corrected.

\section{REFERENCES}

1. Ali MJ, Murphy J, Wormald PJ and Psaltis AJ. (2015): Bony nasolacrimal duct dehiscence in functional endoscopic sinus surgery: radiological study and discussion of surgical implications.J Laryngol Otol., 129: S35-S40.

2. Daraei P and DelGaudio JM. (2014): Inferior meatus surgery for distal nasolacrimal duct obstructions: long-term outcomes and treatment paradigm. JAMA otolaryngology: head \& neck surgery, 140(8), 736-741.

3. Dantas RR. (2010): Lacrimal drainage system obstruction. Seminars in ophthalmology, 25(3): 98-103.

4. DelGaudio JM and Wojno T. (2010): Nasolacrimal duct orifice cysts in adults: a previously unrecognized, easily treatable cause 


\section{MOHAMED H. MOSTAFA et al.,}

of epiphora in adults. Laryngoscope, 117:1830-3.

5. Eloy P, Poirrier AL, Nicoli T, Marlair C, Delahaut G, Leruth $E$ and Rombaux $P$. (2012): Cystic dilation of the distal end of the nasolacrimal duct: underrated cause of epiphora in adults and its endoscopic treatment. Rhinology, 50(4): 436-441.

6. Eriman M, Kinis V, Habesoglu M, Habesoglu TE, Surmeli M, Deveci I and Deveci S. (2012): Role of allergy in primary acquired nasolacrimal duct obstruction. The Journal of craniofacial surgery, 23(6): 16201623.

7. Gadepalli C, Malik V, Inkster C and Lobo C. (2011): Dacryolith in an unusual case of epiphora: open or endoscopic approach?. The Journal of laryngology and otology, 125(12): 1298-1300.

8. Kels BD, Grzybowski A and Grant-Kels JM. (2015): Human ocular anatomy. Clin Dermatol., 33(2):140-146.

9. Mishra K, Hu KY, Kamal S, Andron A, Della Rocca RC, Ali MJ and Nair AG. (2017): Dacryolithiasis: A Review. Ophthalmic Plastic and Reconstructive Surgery, 33(2): 8389.

10. Nemet AY and Vinker S. (2014): Associated morbidity of nasolacrimal duct obstruction--a large community based case-control study. Graefes Arch. Clin. Exp. Ophthalmol,; 252(1):125-30.

11. Patel J, Levin A and Patel BC. (2020): Epiphora. In: Stat Pearls. Treasure Island (FL): Stat Pearls Publishing; August, 2020.
12. Rogers GA, Murchison AP, Wojno TH, and DelGaudio JM. (2010): Inferior meatus endoscopy and directed treatment for epiphora: early experience with a novel approach. Otolaryngology--head and neck surgery: official journal of American Academy of Otolaryngology-Head and Neck Surgery, 140(4), 579-584.

13. Shen GL, Ng JD and Ma XP. (2016): Etiology, diagnosis, management and outcomes of epiphora referrals to an oculoplastic practice. International Journal of Ophthalmology, 9(12): 1751-1755.

14. Takahashi Y, Watanabe $A$ and Matsuda $H$. (2013): Anatomy of secretory glands in the eyelid and conjunctiva: a photographic review. Ophthal Plast Reconstr Surg., 29: 215-219.

15. Vagge A, Ferro Desideri $L$ and Nucci $P$. (2018): Congenital Nasolacrimal Duct Obstruction (CNLDO): A Review. Diseases. ;6(4):96. Published 2018 Oct 22.

16. Viso E, Rodriguez-Ares MT and Gude F. (2012): Prevalence and associations of external punctal stenosis in a general population in Spain. Cornea.; 31(11):1240-1245.

17. Ye L, Peng $Y$, Wang $Y$, Zeng $K$ and Zhang JX. (2015): Pathology of the lower nasolacrimal duct mucosa at multiple time points after lacrimal retrograde catheterization in rabbit. Genetics and molecular research: GMR, 14(3), 7929-7936. 
SCREENING OF EPIPHORA PATIENTS THROUGH ENDOSCOPIC...

\section{دراسة فحص مريض التلدمع باستخدام منظظار الأنف المجرى الأنف |}

محمد حسن مصطفى حسن، عاطف عبد الله المراغى، أحمد محمد عبد الفتاح قسم الأذن والأنف والحنجرة، كلية طب الأزهر

E-mail: $\underline{\text { medohasan02@gmail.com }}$

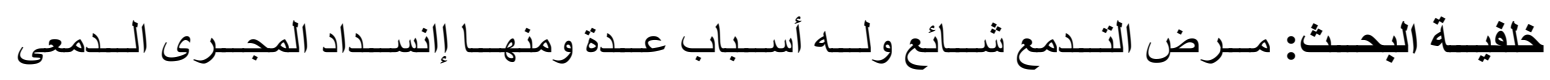

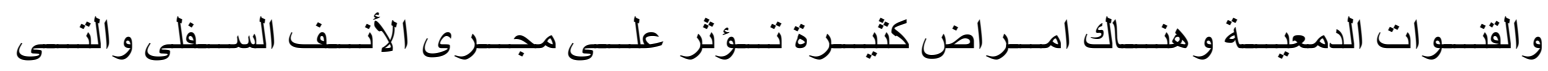

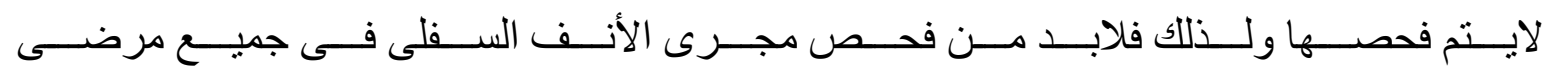
التدمع.


السفلى ومعرفة النسبة المئوية لمرضى التدمع لوجود سبب بالأنف.






بشكوى زيادة دموع العين اما من عين و احدة او من العينين.






جانب واحد كان منهم 8 مرضى من الجانب الايمن و30 من الجانب الايسر.




(4\%), و اثنان من المرضى وجد بهم حصو ات بالقناة الدمعية (4\%).



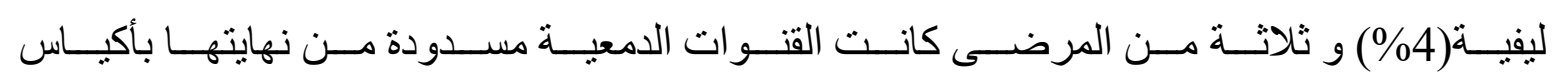





تورم المنطقة حول نهاية القناة الدمعية مما أدى الى انسداد القناة (20\%).

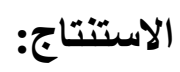


الدمعية فى السيدات أضيق و أطول.


إلى انسدادها.

الكلمات الدالة: التندع, الفحص بالمنظار الأنفى, الصماخ. 